\title{
The Finokalia Aerosol Measurement Experiment - 2008 (FAME-08): an overview
}

\author{
M. Pikridas ${ }^{1,2}$, A. Bougiatioti ${ }^{3}$, L. Hildebrandt ${ }^{4}$, G. J. Engelhart ${ }^{4}$, E. Kostenidou ${ }^{1,2}$, C. Mohr ${ }^{5}$, A. S. H. Prévôt ${ }^{5}$, \\ G. Kouvarakis ${ }^{3}$, P. Zarmpas ${ }^{3}$, J. F. Burkhart ${ }^{6}$, B.-H. Lee ${ }^{4}$, M. Psichoudaki ${ }^{1,2}$, N. Mihalopoulos ${ }^{3}$, C. Pilinis ${ }^{7}$, A. Stohl ${ }^{6}$, \\ U. Baltensperger ${ }^{5}$, M. Kulmala ${ }^{8}$, and S. N. Pandis ${ }^{1,2,4}$ \\ ${ }^{1}$ Department of Chemical Engineering, University of Patras, Greece \\ ${ }^{2}$ Institute of Chemical Engineering and High Temperatures (ICE-HT), FORTH, Patras, Greece \\ ${ }^{3}$ Department of Chemistry, University of Crete, Greece \\ ${ }^{4}$ Center for Atmospheric Particle Studies, Carnegie Mellon University, Pittsburgh, USA \\ ${ }^{5}$ Paul Scherrer Institut, Laboratory of Atmospheric Chemistry, Villigen, Switzerland \\ ${ }^{6}$ Norwegian Institute for Air Research, Kjeller, Norway \\ ${ }^{7}$ Department of Environment, University of the Aegean, Mytilene, Greece \\ ${ }^{8}$ Department of Physics, University of Helsinki, Helsinki, Finland
}

Received: 1 February 2010 - Published in Atmos. Chem. Phys. Discuss.: 10 March 2010

Revised: 7 July 2010 - Accepted: 12 July 2010 - Published: 23 July 2010

\begin{abstract}
A month (4 May to 8 June 2008) of ambient aerosol, air ion and gas phase sampling (Finokalia Aerosol Measurement Experiment 2008, FAME-08) was conducted at Finokalia, on the island of Crete, Greece. The purpose of the study was to characterize the physical and chemical properties of aged aerosol and to investigate new particle formation. Measurements included aerosol and air ion size distributions, size-resolved chemical composition, organic aerosol thermal volatility, water uptake and particle optical properties (light scattering and absorption). Statistical analysis of the aerosol mass concentration variations revealed the absence of diurnal patterns suggesting the lack of strong local sources. Sulfates accounted for approximately half of the particulate matter less than 1 micrometer in diameter $\left(\mathrm{PM}_{1}\right)$ and organics for $28 \%$. The $\mathrm{PM}_{1}$ organic aerosol fraction was highly oxidized with $80 \%$ water soluble. The supermicrometer particles were dominated by crustal components $(50 \%)$, sea salt $(24 \%)$ and nitrates $(16 \%)$. The organic carbon to elemental carbon (OC/EC) ratio correlated with ozone measurements but with a one-day lag. The average OC/EC ratio for the study period was equal to 5.4. For three days air masses from North Africa resulted in a 6-fold increase of particulate matter less than 10 micrometers in diameter $\left(\mathrm{PM}_{10}\right)$ and a decrease of the OC/EC ratio by a factor of 2 . Back trajectory
\end{abstract}

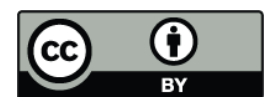

Correspondence to: S. N. Pandis (spyros@andrew.cmu.edu) analysis, based on FLEXPART footprint plots, identified five source regions (Athens, Greece, Africa, other continental and marine), each of which influenced the $\mathrm{PM}_{1}$ aerosol composition and properties. Marine air masses had the lowest $\mathrm{PM}_{1}$ concentrations and air masses from the Balkans, Turkey and Eastern Europe the highest.

\section{Introduction}

Elevated particulate matter (PM) concentrations have been related with increased mortality (Pope et al., 1991, 2009). Fine particles with diameter smaller than $2.5 \mu \mathrm{m}\left(\mathrm{PM}_{2.5}\right)$ are mainly responsible for this association (Pope et al., 2009; Schwartz et al., 1996; Wang et al., 2008). PM is also linked with climate change because of the particles' ability to scatter and absorb light and to act as cloud condensation nuclei $(\mathrm{CCN})$ thus significantly affecting the earth's albedo (Twomey, 1977; Albrecht, 1989; Lohmann and Feichter, 2005).

Even though the importance of PM has been recognized for several decades, there are still significant gaps in our understanding of its sources and atmospheric transformations. It is well established that gaseous sulfuric acid plays a central role in atmospheric nucleation (Kulmala and Kerminen, 2008), but it alone cannot account for the observed nucleation rates in sulfur poor environments (Kulmala et al.,

Published by Copernicus Publications on behalf of the European Geosciences Union. 
2004; Stanier et al., 2004a). The hygroscopicity of inorganic salts has been investigated extensively, but our knowledge of the water uptake of particles consisting of organic-inorganic mixtures is still incomplete (Cruz and Pandis, 2000; Dick et al, 2000; Meyer et al., 2009). Semi-volatile organic compounds (primary or secondary) partition between the gas and particulate phases. Understanding the partitioning of these organic compounds has been recognized as one of the major challenges in our efforts to quantify the rates of formation of secondary organic particulate matter (Robinson et al., 2007). There is little information about the volatility of these organic compounds, especially as the aerosol ages in the atmosphere (Kanakidou et al., 2005; Hallquist et al., 2009). As a part of the EUCAARI (Kulmala et al., 2009) project, the Finokalia Aerosol Measurement Experiment 2008 (FAME-08) was designed to address the above issues by collecting measurements of ultrafine, fine and coarse particles, by monitoring water uptake, size resolved PM composition and size resolved volatility of aged organic aerosol that was transported to Crete from Europe, Asia and Africa.

The Eastern Mediterranean basin is a good area for the investigation of the properties of aged PM (Mihalopoulos et al., 1997; Sciare et al., 2003a; Gerasopoulos et al., 2006). The three major sources of PM in the area are particles and their gaseous precursors from industrialized areas in the Balkans and Eastern Europe (Sciare et al. 2003a, b), Saharan dust transported from the south (Moulin et al., 1998; Kalivitis et al., 2007), and sea spray (Koulouri et al., 2008; Kouvarakis et al., 2002; Sciare et al., 2003b, 2008). Long range transport from Europe contributes significantly to non-sea-salt sulfate (Sciare et al., 2003a) with biogenic emissions of marine origin being the second most important contributor (Mihalopoulos et al., 1997; Kouvarakis et al., 2002).

The majority of aerosol studies in the eastern Mediterranean are focused on megacities such as Athens (Bartzis et al., 2004) and not on remote areas. Few attempts have been made to characterize the PM size distribution away from the urban centers (Lazaridis et al., 2008; Eleftheriadis et al., 2006; Kalivitis et al., 2008) and even fewer to link composition with size (Kavouras and Stephanou, 2002; Schneider et al., 2004; Koulouri et al., 2008). Particle formation has been investigated but without any instrumentation to monitor particles below $10 \mathrm{~nm}$ (Kalivitis et al., 2008). There is almost no information about the water uptake of PM in the area.

FAME-08 combined filter-based methods with continuous measurements of number distribution and chemical composition including water in order to assess the physical, chemical and optical properties of "aged" PM. In this overview paper we briefly describe the full set of measurements of FAME-08 with experimental procedures described in Sect. 4. In Sect. 5 there is an overview of the experimental results including analysis of the diurnal patterns of the various pollutants and analysis of source regions affecting the site during the measurement period. A synthesis of the results is presented in Sect. 6.

\section{Program objectives}

FAME-08 was designed in order to improve our understanding of the physical, chemical and optical properties of aged European aerosol as it is transported from central to southeastern Europe. Its objectives were:

1. Characterization of the PM size, surface area, volume distribution and its physicochemical properties.

2. Characterization of PM chemical composition as a function of size.

3. Improved understanding of the mechanisms of in-situ formation of particles in this area.

4. Quantification of the role of organic matter in the water uptake by PM as a function of aerosol age.

5. Linking the volatility of PM with age, sources, and source areas.

\section{FAME-08 measurements}

\subsection{Site description}

Finokalia $\left(35^{\circ} 24^{\prime} \mathrm{N}, 25^{\circ} 60^{\prime} \mathrm{E}\right)$ is a remote coastal station located in the southeast of the Mediterranean Sea on the island of Crete, Greece (Fig. 1). The nearest lage urban center is Heraklion with 150000 inhabitants located $50 \mathrm{~km}$ west of Finokalia. The Finokalia station is located at the top of a hill at an elevation of $230 \mathrm{~m}$ facing the sea. There is no notable human activity at a range of approximately $15 \mathrm{~km}$ (Kouvarakis et al., 2000).

\subsection{Instrumentation}

FAME-08 was conducted from 4 May to 8 June 2008 and provided continuous measurements of physical and chemical characteristics of PM, air ions, gaseous species and meteorological parameters. The frequency, resolution and the exact operation period of each method are summarized in Table 1.

PM inorganic components: A custom made virtual impactor (Loo and Cork, 1988) was used to collect particles with diameters less than $1.3 \mu \mathrm{m}\left(\mathrm{PM}_{1.3}\right)$ and particles with diameters between 1.3 and $10 \mu \mathrm{m}\left(\mathrm{PM}_{1.3-10}\right)$ daily on Teflon filters (Millipore, Fluoropore membrane filters of $3.0 \mu \mathrm{m}$ pore size). All collected filters were divided in half and extracted in ultrasonic bath with $20 \mathrm{ml}$ of nanopure water for $45 \mathrm{~min}$ for the determination of water soluble ions (Koulouri et al., 2008). For the analysis of anions a Dionex AS4A-SC column was used, with isocratic elution at $2.0 \mathrm{ml} \mathrm{min}^{-1}$ of $\mathrm{Na}_{2} \mathrm{CO}_{3} / \mathrm{NaHCO}_{3}$ as eluent. For the analysis of organic anions, an AS11 analytical column was used, with $\mathrm{NaOH}(0.1-$ $3.5 \mathrm{mM}$ ) as eluent in a gradient mode. For the analysis of cations a CS12-SC column was used, under isocratic conditions with $20 \mathrm{mM}$ MSA eluent and flow rate of $1.0 \mathrm{ml} \mathrm{min}^{-1}$. 
Table 1. Summary of FAME-08 measurements

\begin{tabular}{|c|c|c|c|c|}
\hline Variable & Instrument & Group & Resolution & Period of Operation \\
\hline \multicolumn{5}{|l|}{ Aerosol Size Distribution } \\
\hline $\begin{array}{l}\text { Aerosol Number Distribution } \\
(10-500 \mathrm{~nm})\end{array}$ & TSI 3080 SMPS $^{\mathrm{a}}$ & $\mathrm{CAPS}^{\mathrm{b}}$ & $10 \mathrm{~min}$ & 4-28 May \\
\hline $\begin{array}{l}\text { Aerosol Number Distribution } \\
(10-500 \mathrm{~nm})\end{array}$ & TSI 3034 SMPS a & U. of Aegean & $3 \min$ & 8 May-8 June \\
\hline Positive/Negative Ion Size & Air Ion Spectrometer & U. of Helsinki & $5 \mathrm{~min}$ & 4 May-8 June \\
\hline \multicolumn{5}{|l|}{ Distribution $(0.8-40 \mathrm{~nm})$} \\
\hline \multicolumn{5}{|l|}{ Aerosol Chemical Composition } \\
\hline Aerosol Water & DAASS $^{\mathrm{c}}$ & CAPS $^{b}$ & $10 \mathrm{~min}$ & 4 May-28 May \\
\hline $\begin{array}{l}\mathrm{PM}_{1} \text { (non refractory) Size Resolved } \\
\text { Composition }\end{array}$ & Q-AMS & $\mathrm{PSI}^{\mathrm{e}} / \mathrm{CAPS}^{\mathrm{b}}$ & $3 \mathrm{~min}$ & 8 May-7 June \\
\hline Water Soluble Ions & Steam Sampler & U. of Patras & $17 \mathrm{~min}$ & 6 May-8 June \\
\hline $\mathrm{PM}_{1.3}$ and $\mathrm{PM}_{10}$ Inorganic Ions & Virtual Impactor with Ion Chromatography/ICP-MS ${ }^{\text {h }}$ & $\mathrm{ECPL}^{f}$ & Daily & 4 May -8 June \\
\hline $\mathrm{PM}_{1} \mathrm{OC} / \mathrm{EC}$ & ECPL Sampler with Sunset Laboratories Carbon Analyzer & $\mathrm{ECPL}^{\mathrm{f}}$ & Daily & 4 May-8 June \\
\hline $\mathrm{PM}_{1}$ WSOC & ECPL Sampler with Shimadzu TOC-Vcsh ${ }^{\mathrm{i}}$ & $\mathrm{ECPL}^{\mathrm{f}}$ & Daily & 4 May-8 June \\
\hline \multicolumn{5}{|l|}{ Aerosol Properties } \\
\hline Light Scattering (wet/dry) & Radiance Research Integrating Nephelometer (Model M903) & ECPL $^{f}$ & $5 \mathrm{~min}$ & 4 May-7 June \\
\hline Light Scattering ( 3 wavelengths) & Integrating Nephelometer (TSI Model 3563 ) & U. of Aegean & $5 \mathrm{~min}$ & 4 May-7 June \\
\hline Organic Aerosol Volatility & Thermodenuder & CAPS $^{b}$ & $20 \mathrm{~min}$ & 8 May-8 June \\
\hline Absorption & Magee Scientific Aethalometer (Model AE-20) & $\mathrm{ECPL}^{\mathrm{f}}$ & $5 \min$ & 4 May-8 June \\
\hline Absorption & PSAP (Particle Soot Absorption Photometer) & $\mathrm{ECPL}^{\mathrm{f}}$ & $5 \mathrm{~min}$ & 4 May-8 June \\
\hline \multicolumn{5}{|l|}{ Gaseous Species } \\
\hline $\mathrm{O}_{3}$ & Thermo electron Model 49C & $\mathrm{ECPL}^{\mathrm{f}}$ & $5 \mathrm{~min}$ & 4 May-7 June \\
\hline $\mathrm{O}_{3}$ & Dasibi Model 1008 RS & $\mathrm{ECPL}^{\mathrm{f}}$ & $5 \mathrm{~min}$ & 4 May-7 June \\
\hline $\mathrm{CO}$ & Thermo electron Model 48C & $\mathrm{ECPL}^{\mathrm{f}}$ & $30 \mathrm{~min}$ & 15 May-7 June \\
\hline $\mathrm{SO}_{2}, \mathrm{HNO}_{3}, \mathrm{HCl}$ & Impregnated Paper Filters with IC analysis & $\mathrm{ECPL}^{\mathrm{f}}$ & $6 \mathrm{~h}$ & 4 May-6 June \\
\hline $\mathrm{NH}_{3}$ & Impregnated Glass Fiber Filters with IC analysis & $\mathrm{ECPL}^{\mathrm{f}}$ & $6 \mathrm{~h}$ & 4 May-6 June \\
\hline \multicolumn{5}{|l|}{ Meteorology } \\
\hline Relative Humidity & MP101A Humidity-Temperature & $\mathrm{ECPL}^{\mathrm{f}}$ & $5 \mathrm{~min}$ & 4 May-8 June \\
\hline Light intensity & Pyranometer CM3 & $\mathrm{ECPL}^{\mathrm{f}}$ & $5 \mathrm{~min}$ & 4 May-8 June \\
\hline Temperature & MP101A Humidity-Temperature & $\mathrm{ECPL}^{\mathrm{f}}$ & $5 \mathrm{~min}$ & 4 May-8 June \\
\hline Wind Speed & 05103 Wind Monitor & $\mathrm{ECPL}^{\mathrm{f}}$ & $5 \mathrm{~min}$ & 4 May-8 June \\
\hline Wind Direction & 05103 Wind Monitor & $\mathrm{ECPL}^{\mathrm{f}}$ & $5 \min$ & 4 May-8 June \\
\hline
\end{tabular}

a SMPS: Scanning Mobility Particle Sizer; ${ }^{\text {b }}$ CAPS: Center for Atmospheric Particle Studies at Carnegie Mellon University; ${ }^{c}$ DAASS: Dry-Ambient Aerosol Size Spectrometer;

${ }^{\mathrm{d}}$ Q-AMS: Quadrupole Aerosol Mass Spectrometer; ${ }^{\mathrm{e}}$ PSI: Paul Scherrer Institut; ${ }^{\mathrm{f}}$ ECPL: Environmental Chemical Processes Laboratory (University of Crete); ${ }^{\mathrm{g}}$ IC: Ion chromatography; ${ }^{\mathrm{i}}$ TOC: Total Organic Carbon; ${ }^{\mathrm{h}}$ ICP-MS: Inductively Coupled Plasma Mass Spectrometry.

All ion species were detected by conductivity detectors. $\mathrm{PM}_{1}$ inorganic components were also monitored by a QuadrupoleAerosol Mass Spectrometer with details provided below.

The $\mathrm{PM}_{1.3-10}$ filters were also analyzed for trace metals. An acid microwave digestion procedure followed by Inductively Coupled Plasma Mass Spectrometry (ICP-MS, Thermo Electron X Series) was applied to measure concentrations of $\mathrm{Al}, \mathrm{Ca}, \mathrm{Ti}, \mathrm{V}, \mathrm{Cr}, \mathrm{Mn}, \mathrm{Fe}, \mathrm{Ni}, \mathrm{Cu}, \mathrm{Zn}, \mathrm{Cd}$ and $\mathrm{Pb}$ (Koulouri et al., 2008). The digestion procedure was performed in Teflon vessels (DAP - 60 K, $60 \mathrm{ml} / 40 \mathrm{bar}$ ) in a microwave digestion system (Berghof MWS-2). An internal standard (In, CPI International, S4400-1000241) was added to the digested samples before the ICP-MS analysis (Koulouri et al., 2008).

$\mathrm{PM}_{2.5}$ semi-continuous measurements of water soluble inorganic ions were conducted by a steam sampler-ion chromatograph at a flow rate of $16.7 \mathrm{Lpm}$. The system consisted of three parts: (1) a set of annular diffusion denuders (URG2000) to remove water soluble gaseous species (eg. $\mathrm{NH}_{3}$,
$\mathrm{SO}_{2}, \mathrm{HNO}_{3}$ ), (2) a steam-jet aerosol collector (Khlystov et al., 1995) and (3) two ion chromatographs (IC's) (Metrohm 761 Compact IC) for quantitative mass analysis of anions and cations respectively. A LiF solution of known concentration was mixed with the sample at a flow of $0.1 \mathrm{ml} \mathrm{min}^{-1}$ prior to analysis, as an internal standard. The cations and anions IC were equipped with $1000-\mu l$ and $200-\mu l$ sample loops respectively.

Aerosol Mass Spectrometry: A Quadrupole Aerosol Mass Spectrometer (Q-AMS) from Aerodyne, Inc. was used without drying of the air samples to measure non-refractory (NR) $\mathrm{PM}_{1}$ chemical composition semi-continuously (Jayne et al., 2000; Jimenez et al., 2003). The instrument determined the size distributions of sulfate, nitrate, chloride, ammonium and organics. The calibration of the instrument is described by Hildebrandt et al. (2010). Applying the Kostenidou et al. (2007) algorithm, a total collection efficiency factor (CE) was estimated for the AMS for every two hours. The average $\mathrm{CE}$ for the ambient PM during the campaign was equal 


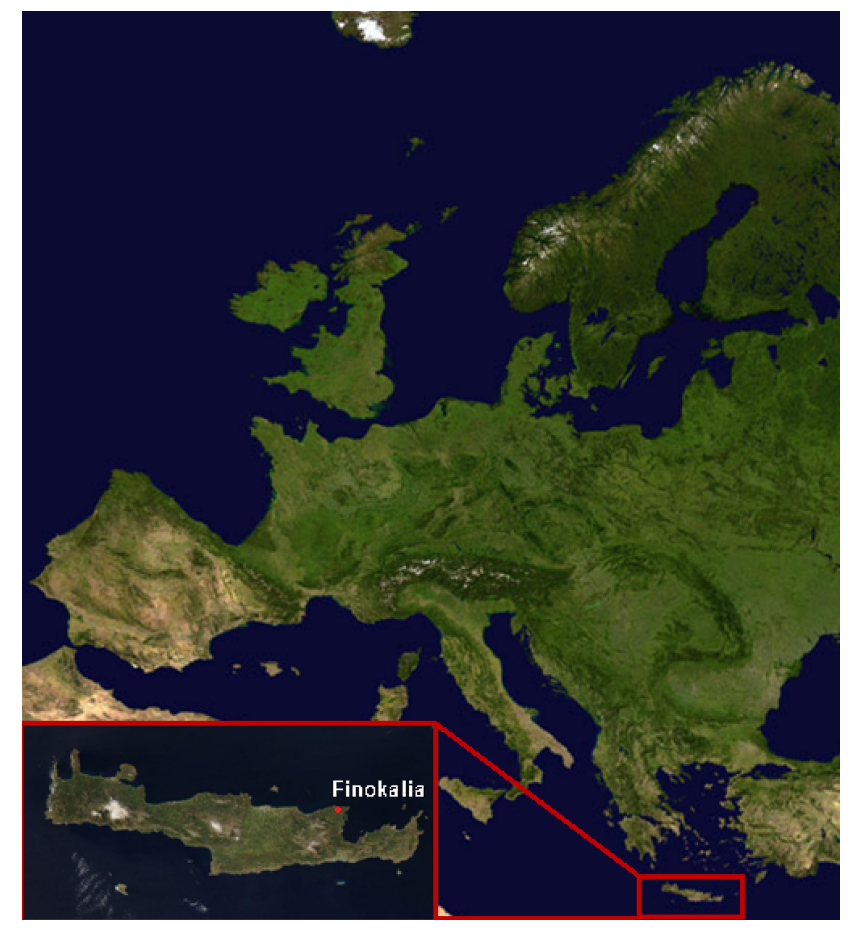

Fig. 1. NASA satellite images of Europe and of the island of Crete, indicating the location of the sampling station at Finokalia.

to 0.85 . A more detailed description of the $\mathrm{CE}$ analysis can be found in Lee (2010).

PM carbonaceous material: $\mathrm{PM}_{1}$ was collected on quartz fiber filters (Whatman QMA, 1851-047), on a daily basis using a custom-built sampler described by Saarikoski et al. (2008). $\mathrm{PM}_{1}$ organic and elemental carbon (OC and EC) was measured using a modification of the NIOSH thermaloptical transmission method, using a carbon analyzer (Sunset Laboratory Inc., Oregon). The method has two distinct phases to differentiate between OC and EC. During the first phase (OC phase) the sample is kept in a helium atmosphere and heated in four steps, reaching $650^{\circ} \mathrm{C}$, while the second phase (oxygen or EC phase) has two consecutive temperature steps, reaching $850^{\circ} \mathrm{C}$. Ambient and thermally denuded organic aerosol was also monitored by the Q-AMS (Hildebrandt et al., 2010).

Water soluble organic carbon (WSOC) was measured daily using a Shimadzu VCSH Total Organic Carbon (TOC) analyzer and $\mathrm{PM}_{1}$ filters (Whatman QMA, 1851-047). A punch of $1 \mathrm{~cm}^{2}$ was extracted with $15 \mathrm{ml}$ of nanopure water for $45 \mathrm{~min}$, filtered (Ion Chrom Acrodisc 13, $0.45 \mu \mathrm{m}$ ) for the retention of the non-soluble species and analyzed with the TOC (Sciare et al., 2008). All soluble carbon containing compounds in the solution were oxidized to form carbon dioxide, which was then measured by a non-dispersive infrared (NDIR) gas analyzer. Next, the inorganic carbon was measured, by acidifying the sample and converting all the carbonates, hydrogen carbonates and dissolved carbon diox- ide to carbon dioxide, which was volatilized by bubbling air through the sample. The produced carbon dioxide was also measured by the NDIR. The water-soluble organic carbon is the difference between the total and inorganic carbon.

Organic aerosol volatility: The volatility of the organic aerosol was measured using a thermodenuder system built based on the design of An et al. (2007). The aerosol flow was directed alternately, via a system of solenoid valves, either through the thermodenuder (set at a predefined temperature) or through a bypass line. In order to avoid recondensation of organic vapors, activated charcoal (4-14 mesh, Sigma Aldrich) was used in the cooling stage. At the end of the thermodenuder, the aerosol path was split in two lines and particles were sent to a Scanning Mobility Particle Sizer (SMPS) and the Q-AMS for real-time measurement of the aerosol size distribution and chemical composition, respectively. The volatility was then determined by comparing the residual aerosol after the thermodenuder to the aerosol that was passed through the bypass (Lee, 2010).

Number distribution: The PM number size distributions were monitored by:

(1) An Air Ion Spectrometer (AIS) which monitored the number size distribution of charged particles in the range of 0.8 to $40 \mathrm{~nm}$ (Mirme et al., 2007);

(2) Two standard SMPS systems (TSI 3936L, TSI 3034) that monitored fine PM in the size range of $10 \mathrm{~nm}$ to $500 \mathrm{~nm}$. The TSI 3034 SMPS monitored the size distribution of ambient and thermally denuded particles in sequence in a temperature controlled environment, while the TSI 3936L was part of the Dry-Ambient Aerosol Size Spectrometer (DAASS) which alternately monitored the distribution of ambient and dried $(\mathrm{RH}<30 \%)$ aerosols at ambient temperature (Stanier et al., 2004b).

PM water and hygroscopicity: The ability of ambient fine particles to absorb water and grow was measured using the Dry-Ambient Aerosol Size Spectrometer (DAASS), (Stanier et al., 2004b). The aerosol path was alternated, via a system of solenoid valves, between the low relative humidity (RH) and ambient conditions. Low RH $(<30 \%)$ was achieved by sampling ambient air through a system of Nafion dryers prior to measurement by an SMPS (TSI 3936L). The water content of aerosols from $10 \mathrm{~nm}$ to $500 \mathrm{~nm}$ was computed as the difference in particle volume distributions at ambient $\mathrm{RH}$ and at low RH (Khlystov et al., 2005). The DAASS was kept at ambient temperature under a weatherproof sunshade. A fan was employed to ensure constant circulation of ambient air around the instruments.

PM optical properties. Aerosol absorption was monitored continuously by two instruments: a Magee Scientific Aethalometer (Model AE-20) and a Particle Soot Absorption Photometer (Radiance Research) operated at 3 wavelengths. Two nephelometers (Radiance Research Integrating Nephelometer, Model M903) were also used connected in series by a diffusion drier. These two nephelometers were kept under a weatherproof sunshade in order to ensure that operation 
was under ambient temperature and RH. Temperature and $\mathrm{RH}$ were measured at the inlet of each instrument. The first nephelometer measured the scattering coefficient at ambient conditions and the second at low RH. A third nephelometer (TSI Model 3563) measured the scattering coefficient at three wavelengths in a controlled environment.

Gaseous species: Continuous measurements of $\mathrm{O}_{3}$ by two instruments (Thermo Electron Model 49C, Dasibi Model 1008 RS) and CO (Thermo Electron Model 48C) using highsensitivity gas analyzers were conducted. Glass fiber filters (GFF Whatman, 1822047) were soaked in a citric acidglycerol solution for the measurement of gas-phase $\mathrm{NH}_{3}$, and paper filters (Whatman, 1441047) were soaked in sodium carbonate/ glycerol solution, for the measurement of gaseous acids $\left(\mathrm{HCl}, \mathrm{H}_{2} \mathrm{SO}_{4}, \mathrm{HNO}_{3}\right)$. These filters were downstream of bulk PM collecting filters (Millipore Fluoropore membrane filters, $0.45 \mu \mathrm{m}$ ) and were replaced every six hours.

Meteorology: Temperature and relative humidity (MP101A Humidity-Temperature, ROTRONIC), wind speed and direction (05103 Wind Monitor, NovaLynx Corporation), and UV intensity (Pyranometer CM3, Kipp \& Zonen) were monitored with 5 min resolution throughout the campaign.

\subsection{Data analysis}

Source Region Categorization. A source region analysis was conducted and the categories used were named by the region from which the air originated: Marine, Africa, Greece, other continental and Athens. Athens was separated from Greece in order to investigate whether the effect of this megacity could be detected at the field site, about $400 \mathrm{~km}$ away. We categorized the air masses based on their source region using the footprint potential emission sensitivity (PES) from 20-day retroplume calculations with the particle dispersion model FLEXPART in backward mode (Stohl et al., 2005), with three hour resolution. Additional information about PES calculations can be found in Seibert and Frank (2004). A retroplume, a replacement for simple back trajectory calculations in the interpretation of atmospheric trace substance measurements (Stohl et al., 2002), was attributed to a region if that region had a PES value above $0.9 \mathrm{~ns} \mathrm{~kg}^{-1}$. For periods in which more than one source region had PES values above the threshold, we attributed that air mass to that region which had the larger area with PES value above the threshold. In order to characterize a retroplume as marine, all PES values above $0.9 \mathrm{~ns} \mathrm{~kg}^{-1}$ had to be located either over sea or over the island of Crete. The marine aerosol that passed over Crete before reaching the field site was not significantly different in composition from the aerosol that was strictly marine and therefore the two were lumped together. A retroplume was characterized as other continental if it was associated with west Turkey or the central and northern Balkans. A flowchart of the decision path is presented in Fig. 2.

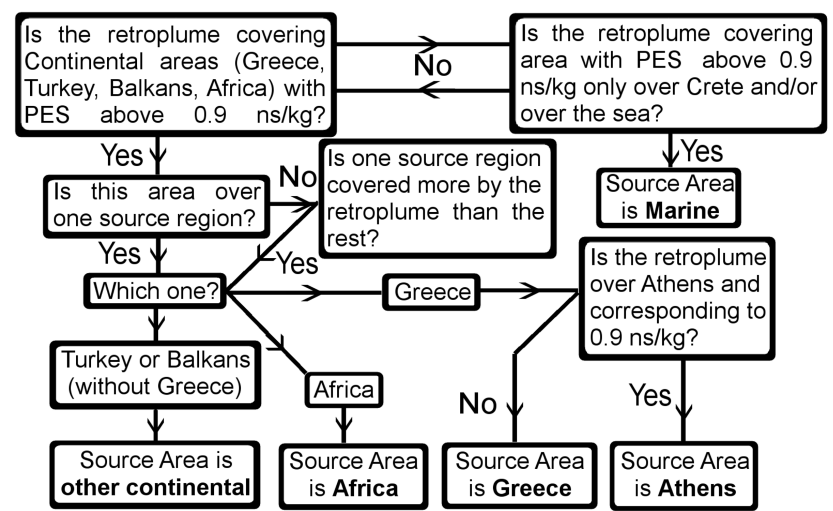

Fig. 2. Source region analysis: flowchart of the decision path.

Statistical Analysis: For the source region analysis, two statistical tests were employed. First, one-way analysis of variance (ANOVA) was employed to reveal if any of the source region contributions had statistically significant differences compared to the rest, at the $99 \%$ confidence level $(\alpha=0.01)$. Assumptions of one-way ANOVA are that all the data are randomly collected and equally distributed (homoscedasticity) and that each data point is independent of all the others. The assumption of homoscedasticity was tested using the Levene test (Wheater and Cook, 2000). If the ANOVA test showed that a difference existed in the contributions from different source regions, then the Tukey-Kramer test was employed for every possible combination of source regions at a confidence level of $99 \%$. Unlike ANOVA, which can only be used to look for at least one different pair among a group without being able to indicate which pair is different, the Tukey-Kramer test can indicate which differences between pairs of groups are significant at a given confidence level, for an uneven dataset and without confidence loss (Wheater and Cook, 2000). The ANOVA test was also employed to find if statistically significant diurnal variation existed at the 95\% confidence level (Hildebrandt et al., 2010).

\section{Overview of measurements}

\subsection{Source region analysis}

Marine aerosol that passed over Crete before reaching the field site had a similar composition as the aerosol that did not pass over Crete. This fact suggests that the local, Cretan sources, influencing the field site are not significant and that the marine aerosols are affected by the naval activity of the Mediterranean.

The origins of the air masses reaching the sampling site during the experiment are given in Fig. 3. The PM concentrations and meteorological conditions grouped by source region are shown in Table 2. 
Table 2. Source region analysis for meteorological, physical and chemical properties.

\begin{tabular}{|c|c|c|c|c|c|c|c|c|c|c|c|}
\hline \multirow[b]{2}{*}{ Variable } & \multirow[b]{2}{*}{ Instrument } & \multicolumn{2}{|c|}{ Marine } & \multicolumn{2}{|c|}{ North Africa } & \multicolumn{2}{|c|}{ Athens } & \multicolumn{2}{|c|}{ Greece } & \multicolumn{2}{|c|}{ Continental } \\
\hline & & Average \pm std & $\begin{array}{l}\text { Number } \\
\text { of values }\end{array}$ & Average \pm std & Number of values & Average \pm std & $\begin{array}{l}\text { Number } \\
\text { of values }\end{array}$ & Average \pm std & $\begin{array}{l}\text { Number } \\
\text { of values }\end{array}$ & Average \pm std & $\begin{array}{l}\text { Number } \\
\text { of values }\end{array}$ \\
\hline $\mathrm{PM}_{1}$ Sulfate $\left(\mu \mathrm{g} / \mathrm{m}^{3}\right)$ & Q-AMS & $3.0 \pm 1.3$ & 590 & $5.0 \pm 1.7$ & 134 & $7.5 \pm 2.2$ & 194 & $6.8 \pm 3.0$ & 216 & $5.9 \pm 2.8$ & 421 \\
\hline $\mathrm{PM}_{1}$ Ammonium $\left(\mu \mathrm{g} / \mathrm{m}^{3}\right)$ & Q-AMS & $1.0 \pm 0.4$ & 590 & $1.7 \pm 0.6$ & 134 & $2.1 \pm 0.6$ & 194 & $1.8 \pm 0.7$ & 216 & $1.8 \pm 0.7$ & 421 \\
\hline $\mathrm{PM}_{1}$ Nitrate $\left(\mu \mathrm{g} / \mathrm{m}^{3}\right)$ & Q-AMS & $0.08 \pm 0.06$ & 590 & $0.10 \pm 0.08$ & 134 & $0.08 \pm 0.04$ & 194 & $0.07 \pm 0.03$ & 216 & $0.09 \pm 0.05$ & 421 \\
\hline Acidity ${ }^{1}$ & Q-AMS & $0.89 \pm 0.19$ & 590 & $0.90 \pm 0.12$ & 134 & $0.75 \pm 0.08$ & 194 & $0.75 \pm 0.11$ & 216 & $0.83 \pm 0.12$ & 421 \\
\hline $\mathrm{PM}_{1}$ Organics $\left(\mu \mathrm{g} / \mathrm{m}^{3}\right)$ & Q-AMS & $2.1 \pm 0.8$ & 590 & $1.9 \pm 0.8$ & 134 & $3.2 \pm 0.9$ & 194 & $2.6 \pm 0.7$ & 216 & $3.2 \pm 1.0$ & 421 \\
\hline Number Concentration $\left(\mathrm{cm}^{-3}\right)$ & SMPS & $2403 \pm 952$ & 1825 & $2435 \pm 1075$ & 167 & $3034 \pm 1043$ & 324 & $3159 \pm 1197$ & 448 & $3068 \pm 1037$ & 812 \\
\hline Air Ions $(<2 \mathrm{~nm})\left(\mathrm{cm}^{-3}\right)$ & AIS & $561 \pm 170$ & 4452 & $662 \pm 225$ & 684 & $511 \pm 1853$ & 1056 & $487 \pm 146$ & 1574 & $502 \pm 149$ & 2436 \\
\hline Aerosol Absorption $\left(\mathrm{Mm}^{-1}\right)$ & PSAP & $4.6 \pm 1.7$ & 4001 & $8.5 \pm 3.4$ & 579 & $5.9 \pm 1.5$ & 960 & $5.4 \pm 1.3$ & 1290 & $5.9 \pm 1.7$ & 2138 \\
\hline$T\left({ }^{\circ} \mathrm{C}\right)$ & Rotronic & $19.0 \pm 3.2$ & 4594 & $24.8 \pm 3.1$ & 684 & $19.6 \pm 3.4$ & 1056 & $19.6 \pm 3.0$ & 1581 & $19.2 \pm 3.9$ & 2429 \\
\hline RH (\%) & Rotronic & $64.6 \pm 19.8$ & 4575 & $46.5 \pm 22.4$ & 682 & $61.6 \pm 20.1$ & 961 & $60.7 \pm 19.3$ & 1568 & $66.9 \pm 18.4$ & 2365 \\
\hline
\end{tabular}

${ }^{1} \mathrm{PM}_{1}$ acidity defined here as the ratio of ammonium to sulfate in molar equivalents as measured by the Q-AMS

Meteorological variables, such as local temperature and relative humidity, changed significantly only when African air masses arrived at the site. Average temperature was on average $4^{\circ} \mathrm{C}$ higher and relative humidity was on average $16 \%$ lower for these periods with African influence. For the rest of the periods the local meteorology was not correlated with the air mass origin.

$\mathrm{PM}_{1}$ sulfate concentrations measured by the AMS were statistically different among all source regions at the $99 \%$ level. Air masses passing over Athens resulted in the highest $\mathrm{PM}_{1}$ sulfate $\left(7.5 \pm 2.2 \mu \mathrm{g} \mathrm{m}^{-3}\right)$, followed by Greece $(6.8 \pm 3.0)$, other continental $\left(5.9 \pm 2.8 \mu \mathrm{g} \mathrm{m}^{-3}\right)$, African $\left(5.0 \pm 1.7 \mu \mathrm{g} \mathrm{m}^{-3}\right)$ and marine air masses $\left(3.0 \pm 1.3 \mu \mathrm{g} \mathrm{m}^{-3}\right)$ (Hildebrandt et al., 2010). The significance of sulfate longrange transport to the area of Finokalia is quite evident from these results, as well as the influence of Athens to the site. $\mathrm{PM}_{1}$ ammonium in marine air masses was statistically lower $\left(1.0 \pm 0.4 \mu \mathrm{g} \mathrm{m}^{-3}\right)$ than that from the other source regions $\left(>1.7 \mu \mathrm{g} \mathrm{m}^{-3}\right) . \mathrm{PM}_{1}$ nitrate concentrations measured by the AMS were low during the study (less than $0.1 \mu \mathrm{g} \mathrm{m}^{-3}$ on average) and were statistically similar for air masses coming from Athens, Greece, other continental and marine source regions. There was a statistically significant increase of $\mathrm{PM}_{1}$ nitrate for African air masses which may be attributed to the increased nitrate content of dust, although it is mostly of supermicron size. Acidity of $\mathrm{PM}_{1}$, defined here as the ratio of AMS ammonium to sulfate (in molar equivalents), was statistically equal for African, marine and other continental source regions but was significantly higher for Greece and Athens $(\alpha=0.01)$. A small fraction of the AMS sulfate could be in the form of organosulfates (Farmer et al., 2010), but all approaches (AMS, filter-based, steam-sampler) used in the study consistently showed that the fine PM was acidic during most of FAME-08.

AMS organic aerosol in air masses from Athens and other continental (not Greece) origin $\left(3.2 \pm 1.0 \mu \mathrm{g} \mathrm{m}^{-3}\right)$ was statistically higher than that from Greece $\left(2.6 \pm 0.7 \mu \mathrm{g} \mathrm{m}^{-3}\right)$. Organic aerosol contributions were statistically smaller when

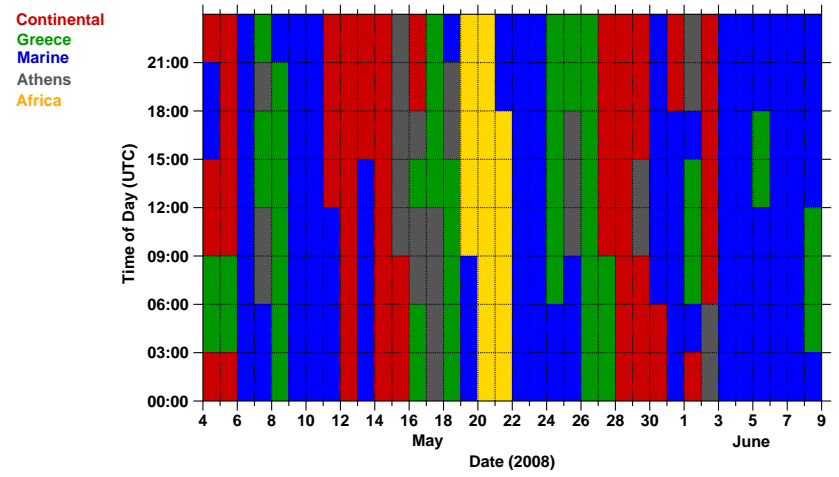

Fig. 3. Source region analysis based on FLEXPART footprint plots. Air masses were categorized based on their source region using PES of their footprint residence time plots (Stohl et al., 2005). A trajectory was attributed to a category if the source region had a PES value above $0.9 \mathrm{~ns} \mathrm{~kg}^{-1}$ in the corresponding footprint plot. Time of day corresponds to UTC.

they originated from Africa $\left(2.1 \pm 0.8 \mu \mathrm{g} \mathrm{m}^{-3}\right)$ and marine areas $\left(1.9 \pm 0.8 \mu \mathrm{g} \mathrm{m}^{-3}\right)$.

Number concentrations of air masses from Athens, Greece and of other continental origin were statistically the same but higher by $25 \%$ than those of marine and African origin. Air ions below $2 \mathrm{~nm}$ followed by AIS were statistically similar for all source regions $\left(\approx 520 \pm 150 \mathrm{~cm}^{-3}\right)$, with the exception of Africa $\left(662 \pm 225 \mathrm{~cm}^{-3}\right)$ which was statistically higher. Aerosol absorption $(522 \mathrm{~nm})$ was higher for aerosols originating from Africa $\left(8.5 \pm 3.4 \mathrm{Mm}^{-1}\right)$ than for all other source regions. This is probably due both to the increased EC concentrations measured during that period and to the high dust levels which can also absorb radiation. Lower absorption was found for air masses originating from Athens and other continental source regions $\left(5.7 \pm 1.6 \mathrm{Mm}^{-1}\right)$. 

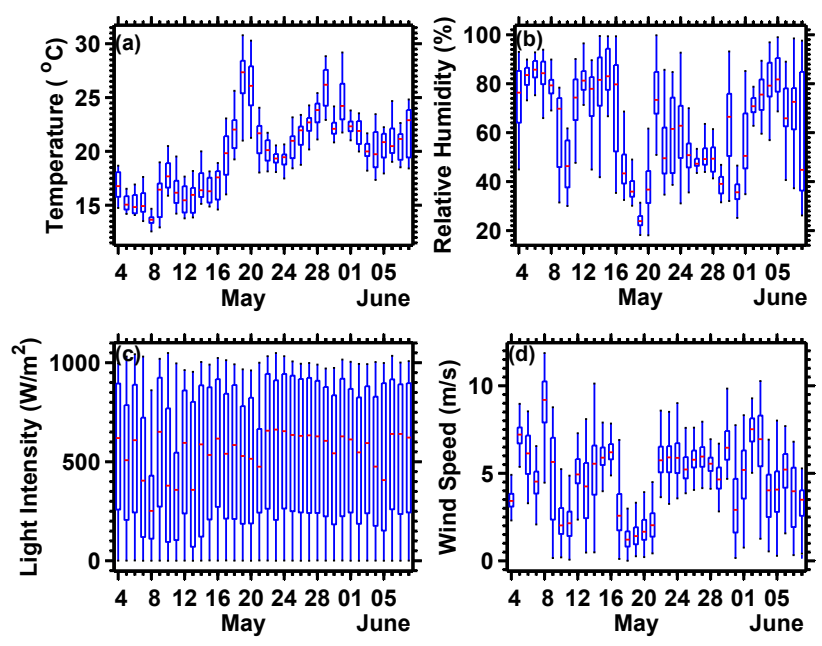

Fig. 4. Daily averages of: (a) ambient temperature, (b) relative humidity, (c) light intensity and (d) wind speed during 4 May to 8 June. Red lines indicate the median, boxes represent the upper and lower quartile and the whiskers extend to the most extreme data points. From 19 May to 21 May (source region Africa) average daily temperature increased and relative humidity decreased.

\subsection{Meteorology}

The daily and diurnal variations of meteorological variables are shown in Figs. 4 and 5, respectively. All diurnal profiles are given with respect to local standard time $(\mathrm{UTC}+2)$. The lowest ambient temperature at the site was $12^{\circ} \mathrm{C}$ and the highest $30.5^{\circ} \mathrm{C}$ while the average temperature was $20^{\circ} \mathrm{C}$. The average daily ambient temperature increased during the study as we moved from late spring to early summer (Fig. 4a). The maximum temperature occurred in the afternoon (2-5 p.m.) and the minimum in the late night (36 a.m.).

Relative humidity varied greatly (Fig. 4b) having an average value for the study equal to $63 \%$, with a minimum of $18 \%$ and a maximum of $99.8 \%$. The diurnal profile of relative humidity had no statistically significant variation at the 95\% confidence level (Fig. 5b).

During FAME-08 solar radiation was intense reaching a maximum value of $1049 \mathrm{~W} \mathrm{~m}^{-2}$, while daily maxima always exceeded $850 \mathrm{~W} \mathrm{~m}^{-2}$. The average solar intensity diurnal profile maximum was $950 \mathrm{~W} \mathrm{~m}^{-2}$ at 12:00 (Fig. 5d). Wind speed was on average $4.6 \mathrm{~m} \mathrm{~s}^{-1}$ and no statistically significant diurnal pattern (at the $95 \%$ level) was observed (Fig. 5c) during FAME-08, indicating no influence from land/sea breeze effects.

\subsection{PM inorganic composition}

$\mathrm{PM}_{1}$ sulfate and ammonium measured by the Q-AMS correlated well with those from $\mathrm{PM}_{1.3}$ filters $\left(R^{2}=0.95\right.$ and 0.86 respectively), thus the bias of the Q-AMS measurements
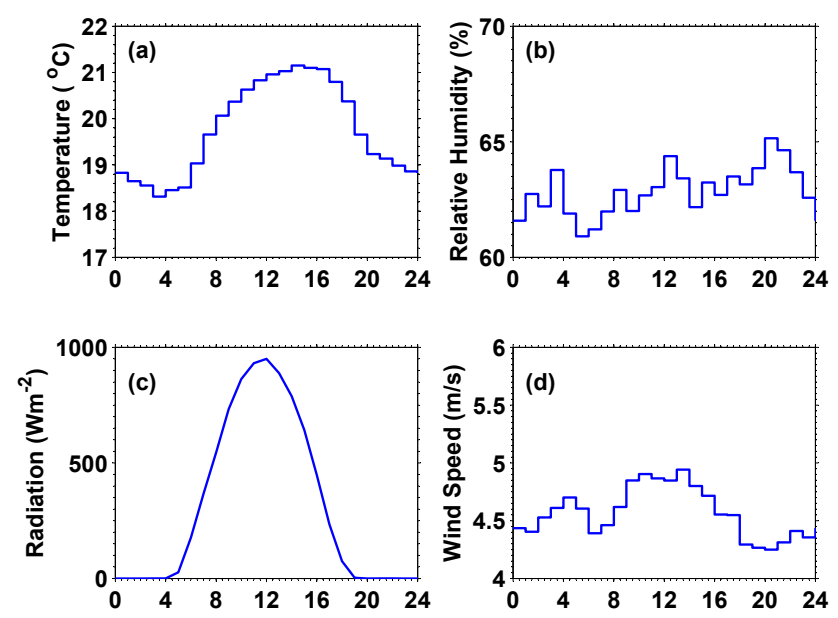

Fig. 5. Average diurnal variation in: (a) ambient temperature: (b) relative humidity, (c) light intensity, and (d) wind speed. Time of day corresponds to local standard time (UTC+2).

due to the potential existence of organosulfates and organonitrates is limited (Farmer et al., 2010). Nitrate did not correlate well because it was associated mainly with $\mathrm{NaNO}_{3}$ and with sizes above the AMS size cut-off. Nitrate concentrations in the $\mathrm{PM}_{1}$ fraction were low, typically below $0.1 \mu \mathrm{g} \mathrm{m}^{-3}$ while in $\mathrm{PM}_{10}$ it was on average $3.9 \mu \mathrm{g} \mathrm{m}^{-3}$.

Figure 6 shows the $\mathrm{PM}_{1}$ sulfate, ammonium, nitrate and organics mass concentrations during the study. One-way ANOVA concluded that none of these species exhibited statistically significant diurnal variations (at the 95\% level) indicating the lack of strong local aerosol sources (Hildebrandt et al., 2010).

Sulfate was the dominant constituent of $\mathrm{PM}_{1}$ accounting for approximately half of the measured $\mathrm{PM}_{1}$ mass (average concentration $4.7 \mu \mathrm{g} \mathrm{m}^{-3}$ ) ranging from a minimum of $0.7 \mu \mathrm{g} \mathrm{m}^{-3}$ to a maximum of $15.5 \mu \mathrm{g} \mathrm{m}^{-3}$. Sulfate concentrations below $1.6 \mu \mathrm{g} \mathrm{m}^{-3}$ were always associated with air masses of marine origin while concentrations above $10 \mu \mathrm{g} \mathrm{m}^{-3}$ were associated with Athens, Greece and other continental sources. Ammonium, which was strongly correlated with sulfate $\left(R^{2}=0.9\right.$ based both on filters and Q-AMS data), accounted for $16 \%$ of the average $\mathrm{PM}_{1.3}$ mass (average concentration $1.3 \mu \mathrm{g} \mathrm{m}^{-3}$ ). EC accounted for $2 \%$ of the average $\mathrm{PM}_{1.3}$ mass and the rest of the inorganic species (e.g. nitrate, phosphate, sodium, potassium, calcium, magnesium and chloride) for $7 \%$. Similar behavior concerning fine inorganic composition is exhibited in other European natural background sites where sulfate is typically the dominant constituent followed by ammonium. This is unlike urban and rural sites where organics dominate (Putaud et al., 2004). Campaign average sulfate concentrations are above the annual average reported for European natural background and elevated sites by a factor of 2-3 (Putaud et al., 2004; Lanz et al., 2009). These high sulfate levels are likely due to the high 

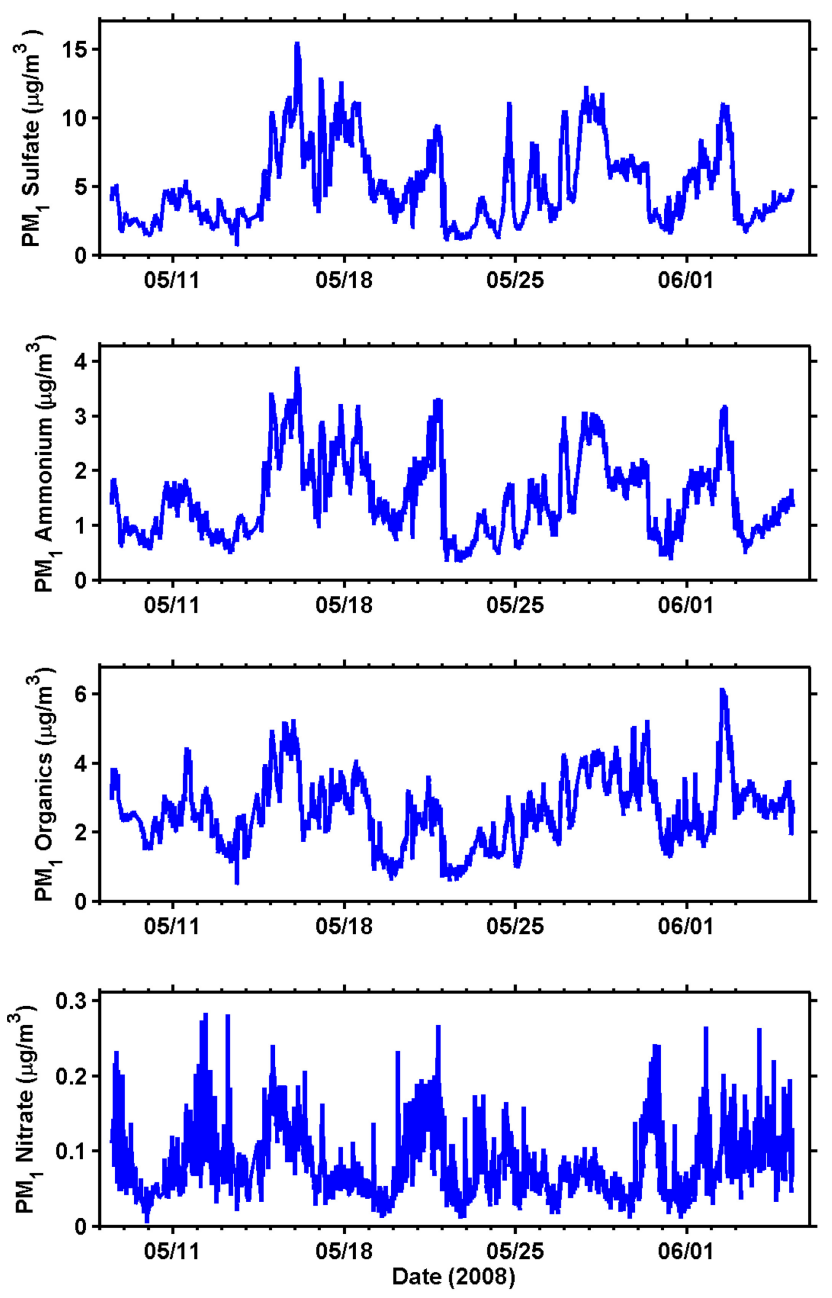

Fig. 6. Time series of $\mathrm{PM}_{1}$ aerosol composition measured by the Q-AMS. Different scales are used for each graph.

photochemical activity in the Eastern Mediterranean during the late spring, summer and early fall, and to the relatively high $\mathrm{SO}_{2}$ emissions in the Balkans, Turkey and Eastern Europe.

$\mathrm{PM}_{1.3}$ and $\mathrm{PM}_{1.3-10}$ inorganic composition based on filter measurements are presented in Fig. 7. The coarse $\left(\mathrm{PM}_{1.3-10}\right)$ fraction was dominated by crustal components $(50 \%)$ and nitrate $(16 \%)$. Sulfate, $\mathrm{Na}^{+}$and $\mathrm{Cl}^{-}$contributed approximately $10 \%$ each to the average coarse mass.

$\mathrm{PM}_{1.3}$ accounted on average for $47 \%$ of the $\mathrm{PM}_{10}$ mass (Fig. 8), reaching $75 \%$ on 17 and 27 May. The minimum contribution $(21 \%)$ was observed when air masses originating from Africa caused a three-day Saharan dust event which started on May 19 and ended on 21 May. During the event the $\mathrm{PM}_{10}$ calcium concentration increased significantly along with the concentrations of other trace metals.

During this study $\mathrm{PM}_{10} \mathrm{Na}^{+}$and $\mathrm{Mg}^{2+}$ correlated well with each other $\left(R^{2}=0.76\right)$, indicating a common origin. Previous studies (Mihalopoulos et al., 1997; Kouvarakis et
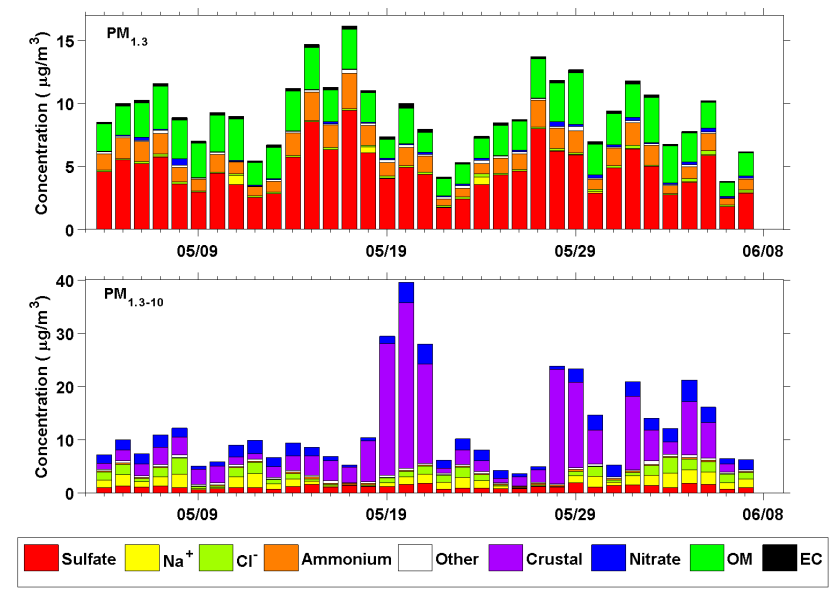

Fig. 7. Daily average of $\mathrm{PM}_{1.3}$ and $\mathrm{PM}_{1.3-10}$ during the study, based on filter measurements. $\mathrm{OM}$ was calculated as $\mathrm{OC} \times 2.2 \mathrm{ac}-$ cording to Hildebrandt et al. (2010). Crustal concentration is calculated using iron as a surrogate according to Sciare et al. (2005). Other is the sum of $\mathrm{PO}_{4}^{3-}$ and $\mathrm{K}^{+}$.

al., 2002) have also reported similar correlations and have attributed both constituents mainly to sea salt. $\mathrm{PM}_{10} \mathrm{Cl}^{-}$and $\mathrm{Na}^{+}$correlated well $\left(R^{2}=0.87\right)$ with an average $\mathrm{Cl}^{-} / \mathrm{Na}^{+}$ mass ratio equal to 0.87 . This ratio is lower by a factor of 2.1 than the typical seawater composition, indicating a deficit in $\mathrm{Cl}^{-}$. This is probably due to the reactions of acids with sea salt that release hydrogen chloride (Seinfeld and Pandis, 2006), which is often observed in polluted coastal areas such as Finokalia (Mihalopoulos et al., 1997).

During this campaign ICP-MS-determined $\mathrm{Al}, \mathrm{Ca}$ and $\mathrm{Fe}$ for $\mathrm{PM}_{1.3-10}$ correlated well with each other $\left(R^{2}>0.83\right)$ indicating a common crustal origin (Sciare et al., 2005). Because ICP-MS did not provide measurements of $\mathrm{Si}$ and because our findings were similar to those of Sciare et al. (2005), we used their approach to determine the dust contribution, which is based on iron instead of the sum of oxides algorithm of Malm et al. (1994). The rest of the elements determined by ICP-MS were typically below $0.01 \mu \mathrm{g} \mathrm{m}^{-3}$ with the exception of $\mathrm{Zn}$, which had an average concentration of $0.1 \mu \mathrm{g} \mathrm{m}^{-3}$. ICP-MS analysis was not conducted for the $\mathrm{PM}_{1}$ fraction as recent studies in the same area have indicated that the elemental concentrations of crustal origin in this size fraction are close to zero (Koulouri et al., 2008).

The particles during FAME-08 always contained water according to both the Q-AMS and the DAASS, even when RH was low. Similar hygroscopic behavior during summer months has been reported before for sulfate rich PM (Klystov et al., 2005).

\subsection{Organic PM}

In order to convert OC to organic matter (OM), OC was multiplied by 2.2 based on the AMS analysis of Hildebrandt et 


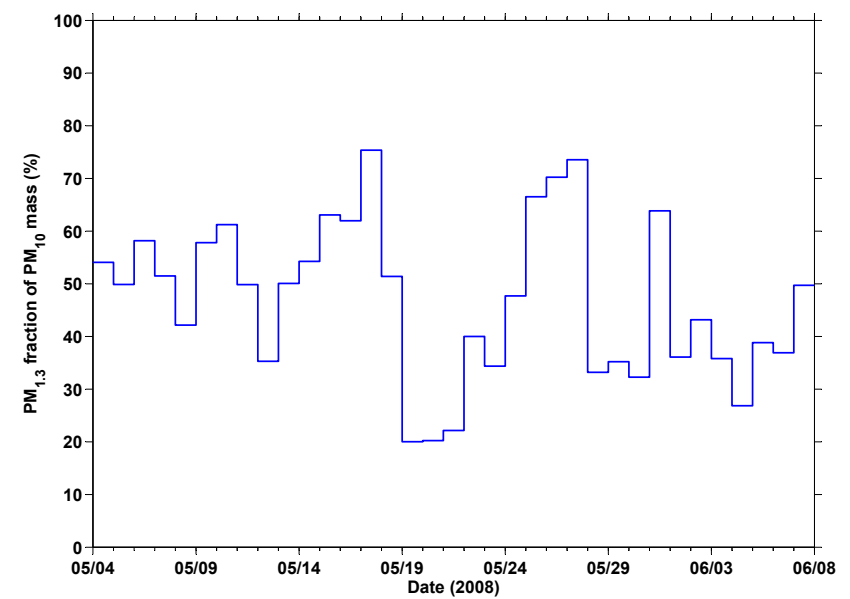

Fig. 8. Mass fraction of $\mathrm{PM}_{1.3}$ over $\mathrm{PM}_{10}$ mass as a function of time.

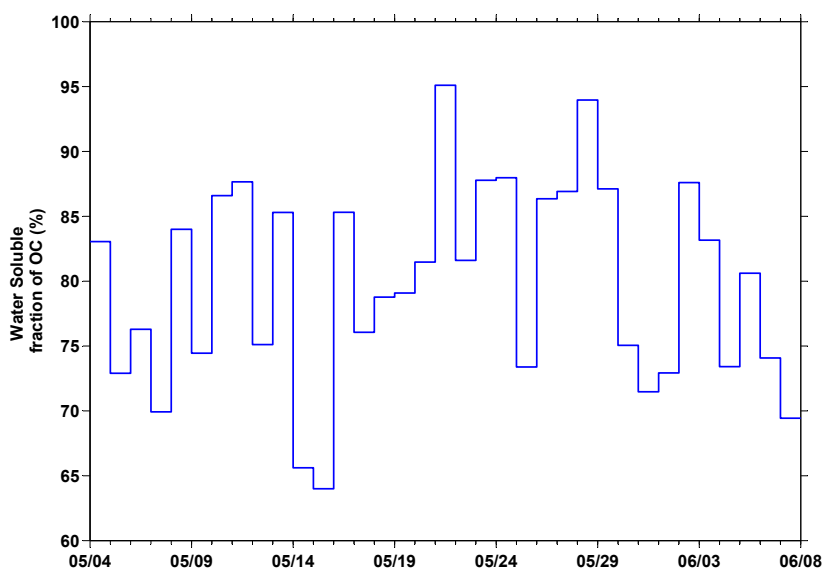

Fig. 9. Percentage of water soluble OC based on $\mathrm{PM}_{1}$ filter measurements. On average $80 \%$ of OC was water soluble.

al. (2010). This value is consistent with the suggestions of Turpin and Lim (2001) for aged aerosol. Q-AMS organics and filter $\mathrm{PM}_{1} \mathrm{OM}$ correlated well $\left(R^{2}=0.79\right)$. OM represented $28 \%$ (average concentration $2.3 \mu \mathrm{g} \mathrm{m}^{-3}$ ) of the $\mathrm{PM}_{1}$ mass on average. Finokalia is similar to other European rural and background sites, where OM represents $20-30 \%$ of the $\mathrm{PM}_{2.5}$ concentration (Putaud et al., 2004) and different than elevated remote sites where OM represents about half of the $\mathrm{PM}_{1}$ mass (Lanz et al., 2009) . The ANOVA test revealed a lack of diurnal pattern of the total organic aerosol measured by the Q-AMS, yet the fraction of the total organic aerosol mass due to fragments at $\mathrm{m} / \mathrm{z}, 43$ and 44 exhibited diurnal patterns of similar phase (Hildebrandt et al., 2010). The mass fragment at $m / z 44$ mostly corresponds to the $\mathrm{CO}_{2}^{+}$ion and can be used as a measure of the extent of oxidation. A detailed analysis of the organic aerosol measured by the AMS during FAME-08 is presented in Hildebrandt et al. (2010).

The water soluble fraction of the $\mathrm{PM}_{1}$ organic content was

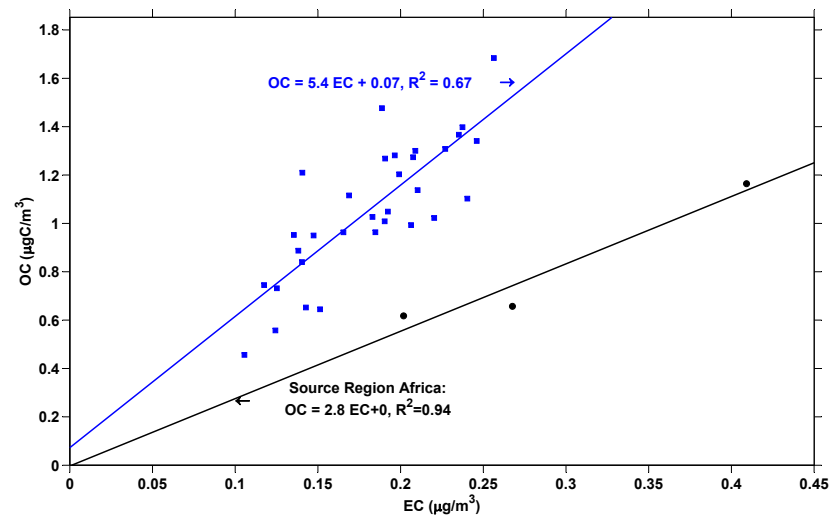

Fig. 10. OC versus EC as determined by $\mathrm{PM}_{1}$ filters. The slope of the OC versus EC line was 5.4 (blue points) for the study period with the exception of 19-21 May (source region Africa), when it was equal to 2.8 (black points).

on average $79.5 \pm 7.8 \%$ (Fig. 9). This large percentage of water soluble carbon supports our hypothesis that organic PM at Finokalia was highly aged. Furthermore, Q-AMS data analysis concluded that $m / z 44$ contributed on average $18 \%$ to the total organic mass (Hildebrandt et al., 2010) which points to a highly oxidized organic aerosol, typical for highly aged air masses (Jimenez et al., 2009).

The $\mathrm{PM}_{1}$ filter based OC/EC slope was equal to 5.4 (Fig. 10) for the study period, with the exception of May 19 to May 21 where the slope was equal to 2.8 due to the high EC concentrations in the African air mass. An OC/EC slope equal to 5.4 suggests that a significant fraction of the organic $\mathrm{PM}$ is secondary, while a value of 2.8 indicates that the secondary formation is limited (Cabada et al., 2004; Lim and Turpin, 2002). All of the organic aerosol was oxygenated (OOA) during FAME-08; hydrocarbon-like organic aerosol (HOA) was not present in detectable amounts (Hildebrandt et al., 2010). Considering that sources influencing Finokalia are expected to contain HOA, these results suggest that HOA was converted to OOA in the 6-36 hours of transport from the source areas to Crete. The OC/EC ratio correlates moderately $\left(R^{2}=0.2\right)$ with daily average ozone, but a time lag between the ozone peak and the OC/EC ratio was observed (Fig. 11). Using a time lag of one day the correlation increased $\left(R^{2}=0.44\right)$ suggesting that the oxidation of organics does not take place near the site but away from it. Similar findings have been reported for urban areas (Cabada et al., 2004).

\subsection{PM size distribution}

Average number, surface area and volume size distributions are presented in Fig. 12. The SMPS-measured average number distribution was centered at $90 \mathrm{~nm}$, the surface area distribution at $245 \mathrm{~nm}$ and the volume distribution at approximately $300 \mathrm{~nm}$. Diurnal profiles of number, surface area and 


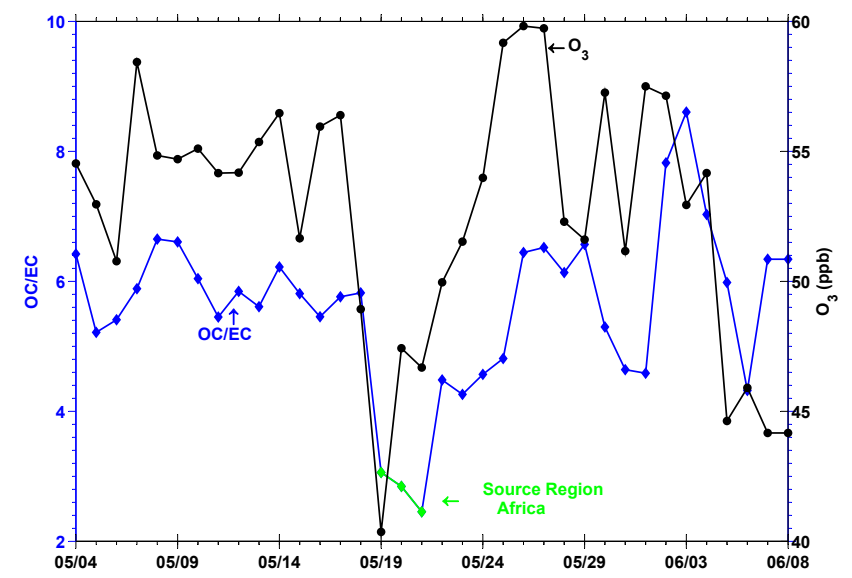

Fig. 11. OC/EC as a function of time. Ozone and OC/EC are moderately correlated and have a time lag of one day.
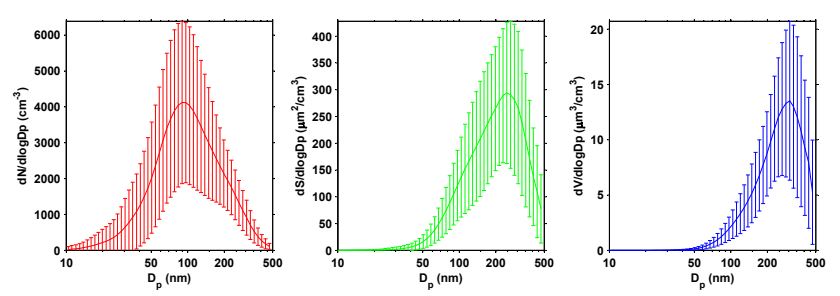

Fig. 12. Campaign average of number, surface area and volume distribution. Error bars represent one standard deviation from the average.

volume distributions did not exhibit any trends, which is consistent with the lack of local sources of particles. The average total number concentration was $2690 \pm 1072 \mathrm{~cm}^{-3}$ (Fig. 13). Particles below $50 \mathrm{~nm}$ did not contribute significantly to the number concentrations $\left(\mathrm{N}_{10-50}=337 \pm 296 \mathrm{~cm}^{-3}\right)$ contrary to larger fractions $\left(\mathrm{N}_{50-100}=1044 \pm 581 \mathrm{~cm}^{-3}\right.$, $\mathrm{N}_{100-500}=1309 \pm 590 \mathrm{~cm}^{-3}$ ). Finokalia exhibits very similar behavior to the European natural background sites where average number concentrations vary between 3000 and $5000 \mathrm{~cm}^{-3}$ and are centered above the $10-30 \mathrm{~nm}$ reported for urban, near-urban and rural sites (Van Dingenen et al., 2004).

Source region analysis concerning number concentration indicates higher contributions from Athens, Greece and other continental source regions than for air masses of marine and African origin. $N_{10-50}$ was also influenced by nucleation and growth of particles. During FAME-08 six nucleation events took place, according to AIS measurements, accompanied by growth of the particles to the Aitken mode. Typical air ion number concentration between $2 \mathrm{~nm}$ to $20 \mathrm{~nm}$ was near zero on non event days and reached up to $100-300 \mathrm{~cm}^{-3}$ during a nucleation event. An analysis of approximately a year of ion measurements at Finokalia including the FAME-08 period can be found in Manninen et al. (2010).
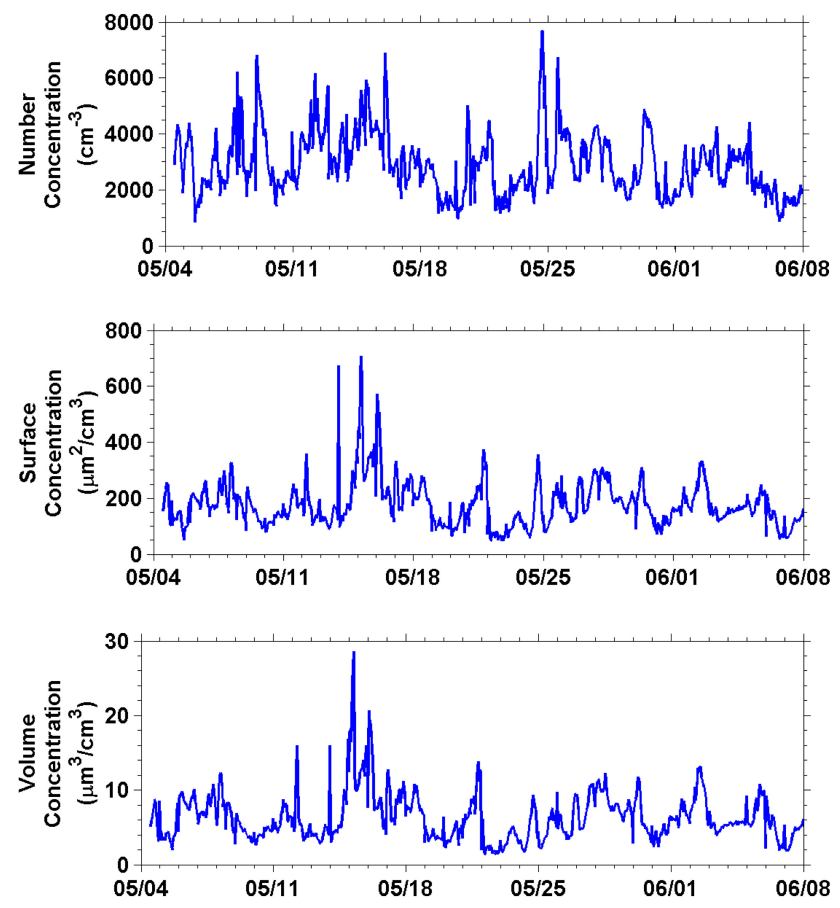

Fig. 13. Time series of number, surface area and volume concentrations for $N_{10-500}$.

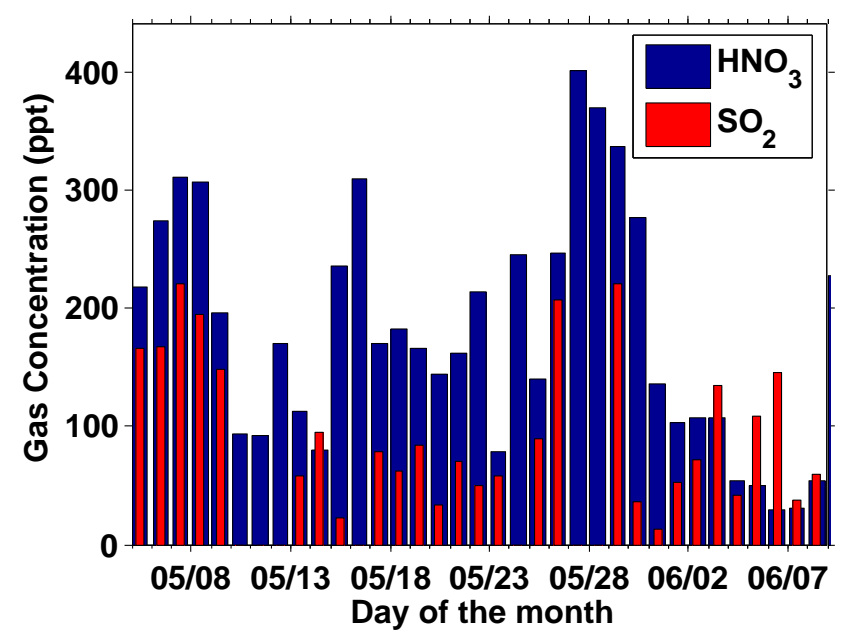

Fig. 14. Daily averages of acidic gaseous species $\left(\mathrm{SO}_{2}, \mathrm{HNO}_{3}\right)$.

\subsection{Gaseous species}

Daily average concentrations of $\mathrm{SO}_{2}$ and $\mathrm{HNO}_{3}$ never exceeded 220 and $400 \mathrm{ppt}$ respectively (Fig. 14). $\mathrm{SO}_{2}$ and $\mathrm{HNO}_{3}$ levels were below the detection limit $(20 \mathrm{ppt})$ for 109 and 13 of the 180 analyzed samples, accounting for $61 \%$ and $7 \%$ of the duration of the campaign, respectively. The average concentrations of the values above the detection limit were $81 \pm 70 \mathrm{ppt}$ for $\mathrm{SO}_{2}$ and $178 \pm 100 \mathrm{ppt}$ for $\mathrm{HNO}_{3}$. The low $\mathrm{SO}_{2} /$ sulfate ratio (average $=0.06$ ) suggests 
that the conversion of $\mathrm{SO}_{2}$ to sulfate is almost complete by the time that the air masses arrive at Crete. Hildebrandt et al. (2010) estimated a maximum $\mathrm{OH}$ value of $1.5 \times 10^{7}$ molecules $\mathrm{cm}^{-3}$, which corresponds to a $\mathrm{SO}_{2}$ consumption rate of $6.3 \%$ per hour in this environment. Several $\mathrm{SO}_{2}$ plumes were observed with concentrations reaching levels above $1 \mathrm{ppb}$. Most of these plumes were associated with transport from coal-fired power plants in northwest Turkey (Canakkale area) and the Peloponnese (Megalopoli area).

\section{Conclusions}

A month of ambient particulate and gas phase sampling was conducted at a remote area in the Eastern Mediterranean in order to characterize the properties and temporal variability of PM. The lack of statistically significant diurnal variation in the bulk concentration of all constituents monitored by the QAMS and in the number concentrations suggests the absence of strong local sources. The coarse $\left(\mathrm{PM}_{1.3-10}\right)$ fraction was dominated by crustal matter $(50 \%)$ and sea salt $(24 \%)$. The dominant $\mathrm{PM}_{1}$ constituents were sulfate and organics, accounting for $55 \%$ and $28 \%$ of the dry mass, respectively. The FAME-08 period was characterized by relatively high sulfate levels compared to those reported in other European background sites, and the sub-micrometer particles were acidic during most of the time.

On average $80 \%$ of the $\mathrm{PM}_{1}$ organic aerosol was water soluble and its OC/EC ratio was equal to 5.4, indicating that the organic aerosol content was mainly secondary and highly oxidized. This conclusion is supported by the Q-AMS analysis of the $\mathrm{PM}_{1}$ organics presented by Hildebrandt et al. (2010). These authors reported that hydrocarbon-like organic aerosol was not detected because all of it had reacted during the one day of transport from the mainland. The OA was highly oxidized and had a surprisingly invariant AMS spectrum regardless of the source region. Hildebrandt et al. (2010) concluded that atmospheric oxidation of OA appears to converge to a highly oxidized organic aerosol, regardless of the original organic aerosol source. The OC/EC ratio was found to correlate $\left(R^{2}=0.44\right)$ moderately with the average ozone concentration of the previous day.

Analysis of retroplumes obtained from a particle dispersion model in backward mode combined with statistical tests was conducted and five source regions were identified (Athens, Greece, other continental, Africa, marine). The hot and dry air masses originating from Africa resulted in an increase in temperature by $4{ }^{\circ} \mathrm{C}$ and a decrease in relative humidity by $16 \%$ on average. Air masses from Africa were also associated with increased dust concentrations, increased aerosol absorption, increased concentrations of small air ions $(<2 \mathrm{~nm})$, lower ozone and a decrease of the OC/EC ratio by half. Source regions Athens, Greece and other continental were associated with higher sulfate, organic and number con- centrations. Air masses of marine origin had the lowest concentrations for all $\mathrm{PM}_{1}$ species.

Acknowledgements. This work was supported by the European Integrated project on Aerosol Cloud Climate and Air Quality Interactions (EUCAARI) and ACCENT. The Carnegie Mellon group acknowledges support by NSF-ATM 0336296. The authors gratefully acknowledge Risto Hillamo of the Finnish Metereological Institute for kindly providing the virtual impactors used in this study.

Edited by: V.-M. Kerminen

\section{References}

Albrecht, B. A.: Aerosols, cloud microphysics, and fractional cloudiness, Science, 245, 1227-1230, 1989

An, W. J., Pathak, R. K., Lee, B. H., and Pandis, S. N.: Aerosol volatility measurement using an improved thermodenuder: Application to secondary organic aerosol, J. Aerosol Sci., 38, 305314, 2007.

Bartzis, J. G., Andronopoulos, S., Kulmala, M., Larsen, B., Lazaridis, M., Lohse, C., Mirabel, P. and Pilinis, C.: The BOND Project: The Marseille and Athens Experimental Campaign. An Overview, J. Aerosol Sci. (European Aerosol Conference Budapest, Hungary 6-10 September 2004), p. 1167, 2004.

Cabada, J. C., Pandis, S. N., Subramanian, R., Robinson, A. L., Polidori, A., and Turpin, B.: Estimating the secondary organic aerosol contribution to $\mathrm{PM}_{2.5}$ using the $\mathrm{EC}$ tracer method, Aerosol Sci. Technol., 38(S1):140-155, 2004.

Cruz, C. N. and Pandis, S. N.: Deliquescence and hygroscopic growth of mixed inorganic-organic atmospheric aerosol, Environ. Sci. Technol., 34, 4313-4319, 2000.

Dick, W. D., Saxena, P., and McMurry, P. H.: Estimation of water uptake by organic compounds in submicron aerosols measured during the Southeastern Aerosol and Visibility Study, J. Geophys. Res., 105, 1471-1479, 2000.

Eleftheriadis, K., Colbeck, I., Housiadas, C., Lazaridis, M., Mihalopoulos, N., Mitsakou, C., Smolık, J., and Zdimal, V.: Size distribution, composition and origin of the submicron aerosol in the marine boundary layer during the eastern Mediterranean "SUB-AERO" experiment, Atmos Environ 40, 62456260, 2006.

Farmer, D. K., Matsunaga, A., Docherty, K. S., Surratt, J. D., Seinfeld, J. H., Ziemann, P. J., and Jimenez, J. L.: Response of an aerosol mass spectrometer to organonitrates and organosulfates and implications for atmospheric chemistry, Proc. Natl. Acad. Sci. USA, 107, 6670-6675, 2010.

Gerasopoulos, E., Kouvarakis, G., Babasakalis, P., Vrekoussis, M., Putaud, J. P., and Mihalopoulos, N.: Origin and variability of particulate matter $\left(\mathrm{PM}_{10}\right)$ mass concentrations over the Eastern Mediterranean, Atmos. Environ., 40, 4679-4690, 2006.

Hallquist, M., Wenger, J. C., Baltensperger, U., Rudich, Y., Simpson, D., Claeys, M., Dommen, J., Donahue, N. M., George, C., Goldstein, A. H., Hamilton, J. F., Herrmann, H., Hoffmann, T., Iinuma, Y., Jang, M., Jenkin, M., Jimenez, J. L., Kiendler-Scharr, A., Maenhaut, W., McFiggans, G., Mentel, Th. F., Monod, A., Prevot, A. S. H., Seinfeld, J. H., Surratt, J. D., Szmigielski, R., and Wildt, J.: The formation, properties and impact of secondary 
organic aerosol: current and emerging issues, Atmos. Chem. Phys., 9, 5155-5236, doi:10.5194/acp-9-5155-2009, 2009.

Hildebrandt, L., Engelhart, G. J., Mohr, C., Kostenidou, E., Bougiatioti, A., DeCarlo, P. F., Prévôt, A. S. H., Baltensperger, U., Mihalopoulos, N., Donahue, N. M., and Pandis, S. N.: Aged organic aerosol in the Eastern Mediterranean: The Finokalia Aerosol Measurement Experiment - 2008, Atmos. Chem. Phys., 10, 4167-4186, doi:10.5194/acp-10-4167-2010, 2010.

Jayne, J.T., Leard, D.C., Zhang, X., Davidovits, P., Smith, K. A., Kolb, C. E., and Worsnop, D. R.: Development of an aerosol mass spectrometer for size and composition analysis of submicron particles, Aerosol Sci. Technol., 33, 49-70, 2000.

Jimenez, J. L., Jayne, J. T., Shi, Q., Kolb, C. E., Worsnop, D. R., Yourshaw, I., Seinfeld, J. H., Flagan, R. C., Zhang, X., Smith, K. A., Morris, J., and Davidovits, P.: Ambient aerosol sampling using the Aerodyne Aerosol Mass Spectrometer, J. Geophys. Res., 108(D7), 8425, doi:10.1029/2001JD001213, 2003.

Jimenez, J. L., Canagaratna, M. R., Donahue, N. M., Prévôt, A. S. H., Zhang, Q., Kroll, J. H., DeCarlo, P. F., Allan, J. D., Coe, H., Ng, N. L., Aiken, A. C., Docherty, K. D., Ulbrich, I. M., Grieshop, A. P., Robinson, A. L., Duplissy, J., Smith, J. D., Wilson, K. R., Lanz, V. A., Hueglin, C., Sun, Y. L., Tian, J., Laaksonen, A. T. R., Rautiainen, J., Vaattovaara, P., Ehn, M., Kulmala, M., Tomlinson, J. M., Collins, D. R., Cubison, M. J., Dunlea, E. J., Huffman, J. A., Onasch, T. B., Alfarra, M. R., Williams, P. I., Bower, K., Kondo, Y., Schneider, J., Drewnick, F., Borrmann, S., Weimer, S., Demerjian, K., Salcedo, D., Cottrell, L., Griffin, R., Takami, A., Miyoshi, T., Hatakeyama, S., Shimono, A., Sun, J. Y., Zhang, Y. M., Dzepina, K., Kimmel, J. R., Sueper, D., Jayne, J. T., Herndon, S. C., Trimborn, A. M., Williams, L. R., Wood, E. C., Kolb, C. E., Baltensperger, U., and Worsnop, D. R.: Evolution of organic aerosol in the atmosphere, Science, 326, 1525-1529, 2009.

Kalivitis, N., Gerasopoulos, E., Vrekoussis, M., Kouvarakis, G., Kubilay, N., Hatzianastassiou, N., Vardavas, I., and Mihalopoulos, N.: Dust transport over the eastern Mediterranean derived from Total Ozone Mapping Spectrometer, Aerosol Robotic Network, and surface measurements, J. Geophys. Res., 112, D03202, doi:10.1029/2006JD007510, 2007.

Kalivitis, N., Birmili, W., Stock, M., Wehner, B., Massling, A, Wiedensohler, A., Gerasopoulos, E., and Mihalopoulos, N.: Particle size distributions in the Eastern Mediterranean troposphere. Atmos. Chem. Phys., 8, 6729-6738, doi:10.5194/acp-8-67292008, 2008.

Kanakidou, M., Seinfeld, J. H., Pandis, S. N., Barnes, I., Dentener, F. J., Facchini, M. C., Van Dingenen, R., Ervens, B., Nenes, A., Nielsen, C. J., Swietlicki, E., Putaud, J. P., Balkanski, Y., Fuzzi, S., Horth, J., Moortgat, G. K., Winterhalter, R., Myhre, C. E. L., Tsigaridis, K., Vignati, E., Stephanou, E. G., and Wilson, J.: Organic aerosol and global climate modelling: A review, Atmos. Chem. Phys., 5, 1053-1123, doi:10.5194/acp-5-1053-2005, 2005.

Kavouras, I. G. and Stephanou, E. G.: Particle size distribution of organic primary and secondary aerosol constituents in urban, background marine, and forest atmosphere, J. Geophys. Res., 107(D8), 4069, doi:10.1029/2000JD000278, 2002.

Khlystov, A., Wyers, G. P., and Slanina, J.: The steam-jet aerosol collector, Atmos. Environ., 29, 2229-2234, 1995.

Khlystov, A., Stanier, C. O., Takahama, S., and Pandis, S.
N.: Water content of ambient aerosol during the Pittsburgh Air Quality Study, J. Geophys. Res., 110, D07S10, doi:10.1029/2004JD004651, 2005.

Kostenidou, E., Pathank, R. K., and Pandis, S. N.: An algorithm for the calculation of secondary organic aerosol density combining AMS and SMPS data, Aerosol Sci. Technol., 41, 1002-1010, 2007.

Koulouri, E., Saarikoski, S., Theodosi, C., Markaki, Z., Gerasopoulos, E., Kouvarakis, G., Makela, T., Hillamo, R., and Mihalopoulos, N.: Chemical composition and sources of fine and coarse aerosol particles in the Eastern Mediterranean, Atmos Environ, 42, 6542-6550, 2008.

Kouvarakis, G., Tsigaridis, K., Kanakidou, M., and Mihalopoulos, N.: Temporal variations of surface regional background ozone over Crete Island in the Southeast Mediterranean, J. Geophys. Res., 105, 399-407, 2000.

Kouvarakis, G., Doukelis, Y., Mihalopoulos, N., Rapsomanikis, S., Sciare, J., and Blumthaler, M.: Chemical, physical, and optical characterization of aerosols during PAUR II experiment. J. Geophys. Res., 107, 8141, doi:10.1029/2000JD000291, 2002.

Kulmala, M., Vehkamäki, H., Petäjä, T., Dal Maso, M., Lauri, A., Kerminen, V. M., Birmili, W., and McMurry, P. H.: Formation and growth rates of ultrafine atmospheric particles: a review of observations, J. Aerosol Sci., 35, 143-176. 2004.

Kulmala, M. and Kerminen, V. M.: On the formation and growth of atmospheric nanoparticles, Atmos. Res., 90, 132-150, 2008.

Kulmala, M., Asmi, A., Lappalainen, H. K., Carslaw, K. S., Pöschl, U., Baltensperger, U., Hov, Ø., Brenquier, J.-L., Pandis, S. N., Facchini, M. C., Hansson, H.-C., Wiedensohler, A., and O'Dowd, C. D.: Introduction: European Integrated Project on Aerosol Cloud Climate and Air Quality interactions (EUCAARI) - integrating aerosol research from nano to global scales, Atmos. Chem. Phys., 9, 2825-2841, doi:10.5194/acp-9-2825-2009, 2009.

Lanz, V. A., Prevot, A. S. H., Alfarra, M. R., Mohr, C., DeCarlo, P. F., Weimer, S., Gianini, M. F. D., Hueglin, C., Schneider, J., Favez, O., D’Anna, B., George, C. and Baltensperger U.: Characterization of aerosol chemical composition by aerosol mass spectrometry in Central Europe: an overview, Atmos. Chem. Phys. Discuss., 9, 24985-25021, doi:10.5194/acpd-924985-2009, 2009.

Lazaridis, M., Dzumbova, L., Kopanakis, I., Ondracek, J., Glytsos, T., Aleksandropoulou, V., Voulgarakis, A., Katsivela, E., Mihalopoulos, N., and Eleftheriadis, K.: $\mathrm{PM}_{10}$ and $\mathrm{PM}_{2.5}$ levels in the Eastern Mediterranean (Akrotiri Research Station, Crete, Greece), Water Air Soil Pollut., 189, 85-101, 2008.

Lee, B. H.: Volatility of Atmospheric Organic Aerosol, Ph.D. thesis, Carnegie Mellon University, Department of Chemical Engineering, Pittsburgh, Pennsylvania, 84-94, 2010.

Lim, H. and Turpin, B. J.: Origins of primary and secondary organic aerosol in Atlanta: Results of time-resolved measurements during the Atlanta Supersite Experiment, Environ. Sci. Technol., 36, 4489-4496, 2002.

Lohmann U. and Feichter J.: Global indirect aerosol effects: a review, Atmos. Chem. Phys., 5, 715-737, doi:10.5194/acp-5-7152005, 2005.

Loo, B. W. and Cork, C. P.: Development of a high efficiency virtual impactor, Aerosol Sci. Technol., 9, 167-176, 1988.

Malm, W. C., Sisler, J. F., Huffman, D., Eldred, R. A., and Cahill, T. 
A.: Spatial and seasonal trends in particle concentration and optical extinction in the United States. J. Geophys. Res., 99, 13471370, 1994.

Manninen, H. E., Nieminen, T., Asmi, A., et al.: EUCAARI ion spectrometer measurements at 12 European sites - analysis of new-particle formation events, Atmos. Chem Phys. Discuss., 10, 11251-11313, doi:10.5194/acpd-10-11251-2010, 2010.

Meyer, N. K., Duplissy, J., Gysel, M., Metzger, A., Dommen, J., Weingartner, E., Alfarra, M. R., Prevot, A. S. H., Fletcher, C., Good, N., McFiggans, G., Jonsson, A. M., Hallquist, M., Baltensperger, U., and Ristovski, Z. D.: Analysis of the hygroscopic and volatile properties of ammonium sulphate seeded and unseeded SOA particles. Atmos. Chem. Phys., 9, 721-732, doi:10.5194/acp-9-721-2009, 2009.

Mihalopoulos, N., Stephanou, E., Kanakidou, M., Pilitsidis, S., and Bousquet, P.: Tropospheric aerosol ionic composition above the Eastern Mediterranean Area, Tellus B, 314-326, 1997.

Mirme, A., Tamm, E., Mordas, G., Vana, M., Uin, J., Mirme, S., Bernotas, T., Laakso, L., Hirsikko, A., and Kulmala, M.: A widerange multi-channel Air Ion Spectrometer, Boreal Environ. Res., 12, 247-264, 2007.

Moulin, C., Lambert, C. E., Dayan, U., Masson, V., Ramonet, M., Bousquet, P., Legrand, M., Balkanski, Y. J., Guelle, W., Marticorena, B., Bergametti, G., and Dulac, F.: Satellite climatology of African dust transport in the Mediterranean atmosphere, J. Geophys. Res., 103, 13137-13144, 1998.

Pope, C. A., Ezzati, M., and Dockery, D. W.: Fine-particulate air pollution and life expectancy in the United States, New Engl. J. Med. 360, 376-386, 2009.

Pope, C. A.: Respiratory hospital admission associated with $\mathrm{PM}_{10}$ pollution in Utah, Salt Lake and Cache Valleys, Arch. Environ. Health, 7, 46-90, 1991.

Putaud, J. P., Raes, F., Van Dingenen, R., Bruggemann, E., Facchini, M. C., Decesari, S., Fuzzi, S., Gehrig, R., Huglin, C., Laj, P., Lorbeer, G., Maenhaut, W., Mihalopoulos, N., Mulller, K., Querol, X., Rodriguez, S., Schneider, J., Spindler, G., ten Brink, H., Torseth, K., and Wiedensohler, A.: European aerosol phenomenology-2: chemical characteristics of particulate matter at kerbside, urban, rural and background sites in Europe, Atmos. Environ., 38, 2579-2595, 2004.

Robinson, A. L., Donahue, N. M., Shrivastava, M. K., Weitkamp, E. A., Sage, A. M., Grieshop, A. P., Lane, T. E., Pierce, J. R., and Pandis, S. N.: Rethinking organic aerosols: Semivolatile emissions and photochemical aging, Science, 315, 1259-1262, 2007.

Saarikoski, S., Timonen, H., Saarnio, K., Aurela, M., Järvi, L., Keronen, P., Kerminen, V. M., and Hillamo, R.: Sources of organic carbon in fine particulate matter in northern European urban air, Atmos. Chem. Phys., 8, 6281-6295, 2008,

http://www.atmos-chem-phys.net/8/6281/2008/.

Sciare, J., Bardouki, H., Moulin, C., and Mihalopoulos, N.: Aerosol sources and their contribution to the chemical composition of aerosols in the Eastern Mediterranean Sea during summertime, Atmos. Chem. Phys., 3, 291-302, 2003a,

http://www.atmos-chem-phys.net/3/291/2003/.

Sciare, J., Cachier, H., Oikonomou, K., Ausset, P., Sarda-Esteve, R., and Mihalopoulos, N.: Characterization of carbonaceous aerosols during the MINOS campaign in Crete, July-August 2001: a multi-analytical approach, Atmos. Chem. Phys., 3, 1743-1757, 2003b, http://www.atmos-chem-phys.net/3/1743/2003/.

Sciare, J., Oikonomou, K., Cachier, H., Mihalopoulos, N., Andreae, M., O., Maenhaut, W., and Estève, R., S.: Aerosol mass closure and reconstruction of the light scattering coefficient over the Eastern Mediterranean Sea during the MINOS campaign, Atmos. Chem. Phys., 5, 2253-2265, 2005,

http://www.atmos-chem-phys.net/5/2253/2005/.

Sciare, J., Oikonomou, K., Favez, O., Liakakou, E., Markaki, Z., Cachier, H., and Mihalopoulos, N.: Long-term measurements of carbonaceous aerosols in the Eastern Mediterranean: evidence of long-range transport of biomass burning, Atmos. Chem. Phys., 8, 5551-5563, doi:10.5194/acp-8-5551-2008, 2008.

Seibert, P. and Frank, A.: Source-receptor matrix calculation with a Lagrangian particle dispersion model in backward mode, Atmos. Chem. Phys., 4, 51-63, doi:10.5194/acp-4-51-2004, 2004.

Seinfeld, J. H. and Pandis, S. N.: Atmospheric Chemistry and Physics: from Air Pollution to Climate Change, John Wiley, New York, USA, 381-384, 1998.

Schneider, J., Borrmann, S., Wollny, A. G., Blasner, M., Mihalopoulos, N., Oikonomou, K., Sciare, J., Teller, A., Levin, Z., and Worsnop, D. R.: Online mass spectrometric aerosol measurements during the MINOS campaign (Crete, August 2001), Atmos. Chem. Phys., 4, 65-80, 2004,

http://www.atmos-chem-phys.net/4/65/2004/.

Stanier, C. O., Khlystov, A., and Pandis, S. N.: Nucleation events during the Pittsburgh Air Quality Study: Description and relation to key meteorological, gas-phase, and aerosol parameters, Aerosol Sci. Technol, 38(S1), 253-264, 2004a.

Stanier, C. O., Khlystov, A., Chan, R., Mandiro, M., and Pandis S. N.: A method for the in-situ measurement of offine aerosol water content of ambient aerosols: the Dry-Ambient Aerosol Size Spectrometer (DAASS), Aerosol Sci. and Technol., 38, Supplement 1, 215-228, 2004b.

Stohl, A.., Eckhardt, S., Forster, C., James, P., Spichtinger, N., and Seibert, P.: A replacement for simple back trajectory calculations in the interpretation of atmospheric trace substance measurements, Atmos. Environ., 36, 4635-4648, 2002.

Stohl, A., Forster, V., Frank, A., Seibert, P., and Wotawa, G.: Technical Note: The Lagrangian particle dispersion model FLEXPART version 6.2, Atmos. Chem. Phys., 5, 2461-2474, doi:10.5194/acp-5-2461-2005, 2005.

Schwartz, J., Dockery, D. W., and Neas, L. M.: Is daily mortality associated specifically with fine particles?, J. Air Waste Manag. Assoc., 46, 927-939, 1996.

Turpin, B. J. and Lim, H. J.: Species contributions to $\mathrm{PM}_{2.5}$ mass concentrations: revisiting common assumptions for estimating organic mass, Aerosol Sci. Technol., 35, 602-610, 2001.

Twomey, S.: The influence of pollution on the shortwave cloud albedo of clouds, J. Atmos. Sci., 34, 1149-1154, 1977.

Van Dingenen, R., Raes, F., Putaud, J.-P., Baltensperger, U., Charron, A., Facchini, M.-C., Decesari, S., Fuzzi, S., Gehrig, R., Hansson, H.-C., Harrison, R. M., Hüglin, C., Jones, A. M., Laj, P., Lorbeer, G., Maenhaut, W., Palmgren, F., Querol, X., Rodriguez, S., Schneider, J., Brink, H., Tunved, P., Tørseth, K., Wehner, B., Weingartner, E., Wiedensohler, A., and Wahlin, P.: A European aerosol phenomenology-1: physical characteristics of particulate matter at kerbside, urban, rural and background sites in Europe, Atmos. Environ., 38, 2561-2577, 2004.

Wang, Z., Hopke, P. K., Ahmadi, G., Cheng, Y. S., and Baron, P. A.: 
Fibrous particle deposition in human nasal passage: The influence of particle length, flow rate, and geometry of nasal airway, J. Aerosol Sci., 39, 1040-1054, 2008.
Wheater C. P. and Cook, P. A.: Using Statistics to Understand the Environment, Routledge, New York, USA, 124-137, 2000. 